\title{
Health effects of attending a public swimming pool: follow up of a cohort of pupils in Paris
}

\author{
Isabelle Momas, Françoise Brette, Anne Spinasse, Fabien Squinazi, William Dab, Bernard \\ Festy
}

\begin{abstract}
Objectives-This study aimed to determine the health effects of attending a well-kept school swimming pool maintained according to French public health regulations.

Methods-This prospective month long study was carried out on a randomised sample of pupils aged 5 to 18 years who attended a private French school with two swimming pools. The children surveyed, helped by their parents, had to fill in questionnaires about their bathing habits and symptoms during the survey period. Inspections of the pool complex were made and these included physicochemical and bacteriological analyses of the pools' water.

Participation-The response rates achieved were $70 \%$ at primary and middle school levels but only $25 \%$ in the high school pupils. Because of this older teenagers were excluded from the final analysis (of 246 children).
\end{abstract}

Results-Compared with non-bathers, bathers experienced fatigue and eye irritation significantly more often $(p<0 \cdot 001)$. The eyes were red $(38 \%$ of bathers) and/or watery (16\%) after swimming but this resolved spontaneously within 24 hours. Bathing behaviour (bath duration, head immersion, wearing swimming goggles) did not affect these incidence rates noticeably. There were no differences between bathers and nonbathers with regard to other symptoms, especially otolaryngological ones. This survey does not allow definite conclusions to be made about verrucas because $22 \%$ of nonbathers were exempted from swimming because of verrucas that they might have caught previously in a pool.

Conclusions-Except for verrucas, the methodology was adequate and daily self reporting of symptoms was feasible. This college largely recruits pupils from higher social classes and is not therefore representative of schools in Paris.

f Epidemiol Community Health 1993; 47: 464-468

Epidemiological investigations conducted in swimming pools have always been motivated by accidental outbreaks of gastroenteritis, ${ }^{1.4}$ of pharyngoconjunctival fever, 58 or of hepatitis 9 occurring in inadequately maintained pools-that is those with poor filtration ${ }^{5}$ or chlorination. ${ }^{1}{ }^{46-8}$ Epidemiologists have only been interested in these unusual conditions and, more recently, in "new" pools such as spas or jaccuzzi ${ }^{10}{ }^{12}$ but, to our knowledge, none have examined the occurrence of ailments in standard, well-kept swimming pools.

To investigate this situation, a prospective decriptive survey was designed in one school. The study population was therefore young, well defined, easy to follow up and perhaps more susceptible to ailments. This investigation was carried out in a private school in Paris.

The objectives of this one month study were to determine the incidence or the prevalence of different symptoms, especially ocular, otolaryngological, and cutaneous symptoms, and to examine whether these were more frequent in pool users than in those who did not swim.

\section{Methods}

STUDY POPULATION

The study was carried out on 600 children selected at random from the register of pupils attending College $S$ during the 1990-91 academic year. This college was attended by approximately 3000 pupils aged between 5 and 20 years. The sample was stratified by age (children from 5 to 11 years old attending primary school, those from 12 to 15 years old attending middle school, and teenagers over 15 at high school).

\section{SWIMMING POOL}

The swimming pool complex of this college comprised two large pools $(12.5 \mathrm{~m}$ by $25 \mathrm{~m})$ with different water depths. They were served by the same continuous treatment system: sand for filtration and chloro-isocyanurates for disinfection. The hydraulicity was classic. Inspection of the pool complex showed that it was operating properly. The maintenance was satisfactory: showers were cleaned three times a day and the pools in the evening. In addition to the college pupils, children from other schools and members of different clubs used the pools; thus about 10000 people were using the swimming facilities each week.

Six water samples were taken from each pool in the morning or in the afternoon-one before and one subsequent to the survey and one per week during the survey. The first and last samples were analysed for the complete assessment of physicochemical and microbiological water quality. The physicochemical quality was measured in terms of temperature, turbidity, conductivity, $\mathrm{pH}$, and chlorine levels (available, free, combined, and total). The microbiological quality was based on fecal coliforms, fecal streptococci, coagulasepositive staphylococci, and Pseudomonas aeruginosa. The other four analyses measured only $\mathrm{pH}$, chlorine levels, and all the bacteria previously mentioned. Techniques used were in accordance with standard French methods. ${ }^{13}$ 
STUDY DESIGN

The survey lasted four weeks from March 18 to April 12, 1991. Before the investigation, surveyed children and their parents received a letter informing them of this study and requesting their written agreement to participate. Confidentiality of collected information was stressed. Primary school teachers and vice principals hand-delivered and collected questionnaires. Three questionnaires had to be filled in for each child.

The first questionnaire dealt with medical history, (previous diseases including allergy, operations, vaccination) and the wearing of spectacles or contact lenses.

The second one described bathing habits: the number of baths at College $S$ and elsewhere (including spas, jaccuzzi and Turkish baths); length of time spent in the water; whether the child took a shower and washed before and after each bath, whether swimming goggles or cap were worn, whether the head was immersed in the water and whether the child practised other sports that might be related to the symptoms studied in this investigation. Those pupils who never bathed during the survey were referred to as non-bathers.

The third questionnaire concerned morbidity and was in a tabular form where local or general symptoms presented by each surveyed child were ticked off as soon as they occurred. These signs could be confirmed by the school nurse and if necessary, by a physician specially recruited for the survey. This doctor then filled in a questionnaire designed to show diagnosed morbidity. Ocular, otolaryngological (runny nose, sore throat, sinusitis, ear infection), and skin abnormalities only were considered. Gastrointestinal diseases and amoebic meningoencephalitis were excluded because they rarely occur in well-kept swimming pools.

\section{STATISTICAL ANALYSES}

Statistical analyses were performed with BMDP software. Incidence rates were evaluated for ocular and otolaryngological signs, but for cutaneous symptoms, only prevalence rates could be determined because the latency period might be longer than the duration of this survey.

Comparisons between bathers and non-bathers were made using $\chi^{2}$ or Fisher's exact test for categorical variables, and analysis of variance for continuous variables after verification of the normality of the distributions.

An unconditional multiple logistic regression was performed to determine the odds ratio (OR) of getting ill or presenting a sign depending on whether the child attended the pool or not and adjusting for potential confounders: gender, level of schooling, and practice of sports which might be related to the sign examined. The ORs were

Table I Follow up of a cohort of French pupils (Paris, 1991). Characteristics of surveyed pupils

\begin{tabular}{lll}
\hline Gender ("\%) & $97 \cdot 2$ boys & $2 \cdot 8$ girls \\
Age (y): & $11 \cdot 3(2 \cdot 4)$ & \\
Mean (SD) & $5-15$ & \\
Range & $32 / 68$ & \\
Dayy/boarders (\%) & & \\
Socio-professional & Father $(\mathrm{n}=232)$ & Mother $(\mathrm{n}=225)$ \\
group (\%): & $87 \cdot 0$ & $48 \cdot 8$ \\
I & $3 \cdot 9$ & $16 \cdot 5$ \\
II & $6 \cdot 5$ & $3 \cdot 2$ \\
III & $0 \cdot 0$ & $0 \cdot 0$ \\
IV & $0 \cdot 0$ & $0 \cdot 4$ \\
V & $2 \cdot 6$ & $0 \cdot 0$ \\
Retired & $0 \cdot 0$ & $31 \cdot 1$ \\
Unemployed & & \\
\hline
\end{tabular}

estimated using the method of maximum likelihood and $95 \%$ confidence intervals based on the standard error of coefficient estimates and normal approximation.

The relative risk $(R R)$ can be deduced from the OR since, as underlined by Hogue et al,${ }^{14} \mathrm{RR}$ may be expressed as a function of OR and of the probability of disease (D) among the exposed population (E) $\mathrm{P}(\mathrm{D} / \mathrm{E})$; the formula is:

$$
R R=O R-(O R-1) \cdot P(D / E)
$$

A method for obtaining approximate confidence intervals of this estimator is given by Hogue et al. ${ }^{14}$

\section{Results}

CONTROL OF THE QUALITY OF THE SWIMMING POOL

The overall quality of the water was very good with reference to the French regulations. We could find very minor anomalies only: slightly high combined chlorine levels $(0.7$ to 1 instead of 0.6 $\mathrm{mg} / \mathrm{l})$ on three occasions and the presence of coagulase-positive staphylococci ( 2 and $3 / 100 \mathrm{ml}$ instead of 0 in $95 \%$ cases) in the shallow pool, and a slight depletion of available free chlorine (1.55 instead of $2 \mathrm{mg} / \mathrm{l}$ ) on one occasion and a slight excess of combined chlorine $(0.8$ to $1 \mathrm{mg} / \mathrm{l})$ on three occasions in the deeper pool. Pool chlorination, filtration, and maintenance procedures were adequate.

\section{RESPONSES}

Eighty four $(69 \cdot 4 \%)$ primary school children, 165 $(67.6 \%)$ middle school, but only $54(22.9 \%)$ high school pupils filled in the three questionnaires. Because of the poor response rate among the older pupils, only those results for children aged less than 16 were analysed.

After sending reminder letters (up to three) a further $11 \%$ of questionnaires were received. Incomplete responses $(10 \cdot 1 \%)$ were not taken into account in this analysis. The percentage of refusers was higher for children below age 11 $(19 \cdot 8 \%)$ than for children above 11 years old $(4 \cdot 9 \%)$. A total of 246 responses were finally obtained and could be analysed.

\section{DEMOGRAPHIC AND SCHOOL LIFE}

\section{CHARACTERISTICS (table I)}

The age, gender, and socioeconomic distribution of this sample of 246 children is similar to that for all pupils (adolescents excluded) at the college. Boys are predominant in this population; only a few girls attend the primary school and none the middle or high schools. Most pupils are dayboarders. The children's socioeconomic status is largely above average and quite homogeneous.

\section{BATHING HABITS}

Only 36 pupils (14.6\%) never bathed during the survey. Most pupils $(83.1 \%$ at the primary school, $86.5 \%$ at middle school) bathed in the swimming pool of the college. Most of them swam during the swimming class but few of them $(8.4 \%$ at primary school, $9 \cdot 2 \%$ at middle school) also attended these pools individually.

Bathing behaviour (table II) is very similar at primary and middle school. On average, children 
bathed once a week, for 45 minutes. Most of them took a shower but omitted to wash themselves before and after each bathing session. Only $22 \%$ of bathers wore swimming goggles. Swimming caps were not often used but were more commonly worn by the youngest pupils.

\section{DECLARED MORBIDITY}

Around $68 \%$ of the pupils suffered at least one symptom during the survey. The local problems most commonly encountered were blotchy skin, runny nose, itch, verruca, and watery eyes. In terms of general signs, fatigue, headache, and fever were noted. Face rash $(6.1 \% v 0, \mathrm{p}<0.05)$ and fever $(13.8 \%$ v $4.9 \%, \mathrm{p}=0.03)$ were reported significantly more often in middle school than in primary school pupils. No statistically significant differences were observed between primary and middle school pupils with regard to other symptoms.

Compared with non-bathers, bathers had a significantly lower rate of verruca but experienced fatigue and eye disorders such as red or watery eyes significantly more often (table III). These results remain statistically significant after adjusting for potential confounders (level of schooling, gender, ...). The eye disorders were constantly reported on each week and in each pool. Their incidence rates did not seem to be

Table II Follow up of a cohort of French pupils (Paris, 1991). Bathing habits in surveyed pupils attending the swimming pool during the survey

\begin{tabular}{|c|c|c|c|c|}
\hline Bathing habits & $\begin{array}{l}\text { All bathers } \\
\text { surveyed }(n=210)\end{array}$ & $\begin{array}{l}\text { Primary school } \\
(n=69)\end{array}$ & $\begin{array}{l}\text { Middle school } \\
(n=141)\end{array}$ & p value \\
\hline $\begin{array}{l}\text { No of baths per child: } \\
\text { Mean (SD) } \\
\text { Median }\end{array}$ & $\begin{array}{l}3 \cdot 87(1 \cdot 82) \\
4\end{array}$ & $\begin{array}{l}3 \cdot 84(1 \cdot 85) \\
4\end{array}$ & $\begin{array}{l}3.94(1.78) \\
4\end{array}$ & NS \\
\hline $\begin{array}{l}\text { Duration of bath }(\mathrm{min}) \text { : } \\
\text { Mean (SD) } \\
\text { Median }\end{array}$ & $\begin{array}{l}42 \cdot 5(11 \cdot 2) \\
45\end{array}$ & $\begin{array}{l}41 \cdot 8(9 \cdot 4) \\
45\end{array}$ & $\begin{array}{l}44 \cdot 2(14 \cdot 6) \\
45\end{array}$ & NS \\
\hline $\begin{array}{l}\text { Taking a shower }(\%) \text { : } \\
\text { Before bathing }(n=195) \\
\text { After bathing }(n=190)\end{array}$ & $\begin{array}{l}96 \cdot 4 \\
84 \cdot 7\end{array}$ & $\begin{array}{l}96 \cdot 9 \\
80 \cdot 0\end{array}$ & $\begin{array}{l}96 \cdot 2 \\
86 \cdot 9\end{array}$ & $\begin{array}{l}\text { NS } \\
\text { NS }\end{array}$ \\
\hline $\begin{array}{l}\text { Washing (\%): } \\
\text { Before bathing }(n=190) \\
\text { After bathing }(n=187)\end{array}$ & $\begin{array}{l}1 \cdot 1 \\
4 \cdot 3\end{array}$ & $\begin{array}{l}3 \cdot 2 \\
6 \cdot 3\end{array}$ & $\begin{array}{l}0 \cdot 2 \\
3 \cdot 2\end{array}$ & $\begin{array}{l}\text { NS } \\
\text { NS }\end{array}$ \\
\hline $\begin{array}{l}\text { Wearing swimming goggles } \\
(\%)(n=193) \\
\text { Wearing swimming cap }(\%)\end{array}$ & $22 \cdot 3$ & $25 \cdot 4$ & $20 \cdot 8$ & NS \\
\hline $\begin{array}{l}\text { Wearing swimming cap }(\%) \\
(n=194) \\
\text { Head immersion }(\%)(n=194) \\
\text { Opening eyes }(\%)\end{array}$ & $\begin{array}{r}5 \cdot 2 \\
94 \cdot 8 \\
78 \cdot 9\end{array}$ & $\begin{array}{l}11 \cdot 1 \\
95 \cdot 3 \\
73 \cdot 8\end{array}$ & $\begin{array}{r}2 \cdot 3 \\
94 \cdot 6 \\
81 \cdot 5\end{array}$ & $\begin{array}{l}\mathrm{p}=0 \cdot 024 \\
\mathrm{NS} \\
\mathrm{NS}\end{array}$ \\
\hline
\end{tabular}

noticeably affected by differences in bathing behaviour (table IV).

TableV shows that complaints about draughts are statistically related to over-reporting of four signs: itch, rash, runny nose, and cough.

\section{DIAGNOSED MORBIDITY}

There were no differences between bathers and non-bathers with regard to diseases diagnosed during the survey but only 10 children were diagnosed.

\section{Discussion}

To our knowledge this is the first study aiming to determine the frequency of ailments that might occur in a cohort of pupils attending an a priori well-maintained swimming pool, the quality of which is corroborated by physicochemical and bacteriological analyses.

Such an investigation based on daily self reporting of symptoms was feasible in College $S$ at both primary and middle school levels where a response rate of about $70 \%$ was achieved. "Non-responses" in total, which included non-responders per se, incomplete responses, and refusals, did not differ statistically significantly from "responses" with regard to sociodemographic and school characteristics. Therefore, the 246 children who answered seemed to be representative of all the children aged less than 16 years attending this college.

With regard to diagnosed morbidity, the investigation was weak, probably because the study period was too short. The small number of illnesses diagnosed does not therefore permit definite conclusions to be drawn.

The college selected for this study is not representative of schools in Paris. Most of the pupils are boys and day-boarders. Some $70 \%$ of mothers have a job and there is a very large predominance of children from the higher social classes. Thus findings from such a sample cannot be extrapolated to the general population. Nevertheless, while avoiding generalisation, we can discuss bathing habits and symptoms presented by this surveyed population.
Table III Follow up of a cohort of French pupils (Paris, 1991). Declared morbidity according to bathing exposure during the survey

\begin{tabular}{|c|c|c|c|c|c|}
\hline \multirow[b]{2}{*}{$\begin{array}{l}\text { Symptoms experienced at least once } \\
\text { during the survey (\%) }\end{array}$} & \multicolumn{3}{|c|}{ Bathing exposure } & \multirow[b]{2}{*}{$\begin{array}{l}\text { Odds } \\
\text { ratio }\end{array}$} & \multirow[b]{2}{*}{$(95 \% C I)$} \\
\hline & $\begin{array}{l}\text { No } \\
(n=36)\end{array}$ & $\begin{array}{l}Y e s \\
(n=210)\end{array}$ & $p$ value & & \\
\hline $\begin{array}{l}\text { Blotch: } \\
\text { Face }\end{array}$ & $11 \cdot 1$ & $41 \cdot 9$ & $p=0 \cdot 0004$ & $5 \cdot 03^{\star}$ & $(1 \cdot 68,15 \cdot 1)$ \\
\hline $\begin{array}{l}\text { Face } \\
\text { Eye }\end{array}$ & 0 & $2 \cdot 9$ & NS & - & \\
\hline $\begin{array}{l}\text { Eye } \\
\text { Body }\end{array}$ & $5 \cdot 6$ & $37 \cdot 6$ & $\mathrm{p}=0 \cdot 0002$ & $10 \cdot 2 \dagger$ & $(2 \cdot 36,43 \cdot 9)$ \\
\hline $\begin{array}{l}\text { Body } \\
\text { Foot }\end{array}$ & $2 \cdot 8$ & $4 \cdot 3$ & NS & $1 \cdot 27^{\star}$ & $(0 \cdot 15,10 \cdot 8)$ \\
\hline $\begin{array}{l}\text { Foot } \\
\text { Itch: }\end{array}$ & $2 \cdot 8$ & $3 \cdot 8$ & NS & $1 \cdot 16^{\star}$ & $(0.13,9 \cdot 95)$ \\
\hline $\begin{array}{l}\text { Itch: } \\
\text { Face }\end{array}$ & $8 \cdot 3$ & $23 \cdot 3$ & $p=0.0417$ & $3 \cdot 14^{\star}$ & $(0 \cdot 86,11 \cdot 4)$ \\
\hline $\begin{array}{l}\text { Face } \\
\text { Eye }\end{array}$ & 0 & $3 \cdot 4$ & NS & & \\
\hline $\begin{array}{l}\text { Eye } \\
\text { Body }\end{array}$ & $2 \cdot 8$ & $12 \cdot 9$ & NS & $5 \cdot 84 \dagger$ & $(0 \cdot 72,47 \cdot 4)$ \\
\hline $\begin{array}{l}\text { Body } \\
\text { Foot }\end{array}$ & $2 \cdot 8$ & $7 \cdot 7$ & NS & $2 \cdot 57^{\star}$ & $(0.30,21 \cdot 8)$ \\
\hline $\begin{array}{l}\text { Foot } \\
\text { Rash: }\end{array}$ & $2 \cdot 8$ & $5 \cdot 8$ & NS & $1 \cdot 94^{\star}$ & $(0 \cdot 24,15 \cdot 7)$ \\
\hline $\begin{array}{l}\text { Rash: } \\
\text { Face }\end{array}$ & $2 \cdot 8$ & $7 \cdot 7$ & NS & $2 \cdot 22^{\star}$ & $(0 \cdot 28,17 \cdot 8)$ \\
\hline $\begin{array}{l}\text { Face } \\
\text { Body }\end{array}$ & 0 & $4 \cdot 8$ & NS & & \\
\hline $\begin{array}{l}\text { Body } \\
\text { Crack in skin }\end{array}$ & $2 \cdot 8$ & $4 \cdot 3$ & NS & $1 \cdot 04^{\star}$ & $\begin{array}{l}(0 \cdot 12,8 \cdot 94) \\
(0.13,9 \cdot 62)\end{array}$ \\
\hline $\begin{array}{l}\text { Crack in skin } \\
\text { Verruca }\end{array}$ & $2 \cdot 8$ & $3 \cdot 8$ & NS & $1 \cdot 13^{\star}$ & $\begin{array}{l}(0.13,9 \cdot 62) \\
(0.15,0.89)\end{array}$ \\
\hline $\begin{array}{l}\text { Verruca } \\
\text { Watery eye }\end{array}$ & $\begin{array}{c}25 \cdot 0 \\
0\end{array}$ & $11 \cdot 6$ & $p=0.0302$ & $0 \cdot 36^{\star}$ & \\
\hline $\begin{array}{l}\text { Watery eye } \\
\text { Runny nose }\end{array}$ & $\begin{array}{c}0 \\
36 \cdot 1\end{array}$ & $15 \cdot 8$ & $\mathrm{p}=0.0215$ & $0.99 t$ & $(0.47,2.08)$ \\
\hline Sore throat & $\begin{array}{r}36 \cdot 1 \\
8 \cdot 6\end{array}$ & $36 \cdot 5$ & $\begin{array}{l}\text { NS } \\
\text { NS }\end{array}$ & $2 \cdot 16 \dagger$ & $(0.62,7.59)$ \\
\hline Cough & $\begin{array}{r}8 \cdot 6 \\
16 \cdot 7\end{array}$ & $\begin{array}{l}11 \cdot 0 \\
10 \cdot 1\end{array}$ & $\begin{array}{l}\text { NS } \\
\text { NS }\end{array}$ & $0.54 t$ & $(0 \cdot 20,1 \cdot 46)$ \\
\hline Earache & $8 \cdot 3$ & $9 \cdot 0$ & NS & $1 \cdot 10 \dagger$ & $(0.31,3.96)$ \\
\hline Fever & $5 \cdot 7$ & $11 \cdot 6$ & NS & $2.06 \dagger$ & $(0 \cdot 46,9 \cdot 28)$ \\
\hline Headache & $16 \cdot 7$ & $19 \cdot 1$ & NS & $1 \cdot 16 \dagger$ & $(0.45,2.99)$ \\
\hline Fatigue & 8.6 & $25 \cdot 8$ & $p=0.0255$ & $3.70 \dagger$ & $(1 \cdot 08,12 \cdot 7)$ \\
\hline Any one of those symptoms & $47 \cdot 2$ & $71 \cdot 8$ & $p=0.0034$ & $2 \cdot 86^{\star}$ & $(1.37,5.99)$ \\
\hline
\end{tabular}

$\mathrm{CI}=$ confidence interval

*Logistic regression model including gender, level of schooling, practice of sport, that may be related to the studied symptom

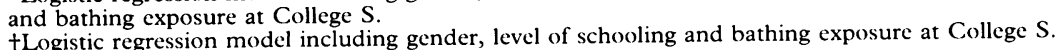


Table IV Follow up of a cohort of French pupils (Paris, 1991). Relative risks (RR) of "eve irritation" and of "watery eyes" according to bathing behaviour (logistic regression model adjusted for duration of bathing)

\begin{tabular}{|c|c|c|c|c|}
\hline \multirow[b]{2}{*}{ Bathing bihasiour } & \multicolumn{2}{|c|}{ Eve irritation } & \multicolumn{2}{|c|}{ Watery eyes } \\
\hline & $R R$ & $\left(95^{\circ} \circ C I\right)$ & $R R$ & $(95 \% C I)$ \\
\hline \multicolumn{5}{|c|}{$\mathrm{W}^{\prime}$ caring swimming goggles: } \\
\hline No & $1 \cdot 00$ & & $1 \cdot 00$ & \\
\hline Yes & $0 \cdot 88$ & $(0.67,1.16)$ & 0.54 & $(0.44,0.63)$ \\
\hline \multicolumn{5}{|l|}{ Head immersion: } \\
\hline No & $1 \cdot 00$ & & $1 \cdot 00$ & \\
\hline Yes & $1 \cdot 87$ & $(0.83,4.23)$ & $0 \cdot 98$ & $(0.76,1 \cdot 26)$ \\
\hline \multicolumn{5}{|c|}{ Opening the eyes underwater: } \\
\hline No & $1 \cdot 00$ & & $1 \cdot 00$ & \\
\hline Yes & $0 \cdot 81$ & $(0.61,1.07)$ & $0 \cdot 41$ & $(0.36,0.47)$ \\
\hline \multicolumn{5}{|l|}{ Wearing spectacles: } \\
\hline No & $1 \cdot 00$ & & $1 \cdot 00$ & \\
\hline Yes & 1.03 & $(0 \cdot 42,2 \cdot 54)$ & $1 \cdot 35$ & $(1 \cdot 14,1 \cdot 59)$ \\
\hline
\end{tabular}

Table $V$ Follow up of a cohort of French pupils (Paris, 1991). Statistically significant associations between user's opinion about the quality of the pool environment and self reporting of symptoms

\begin{tabular}{llcl}
\hline $\begin{array}{l}\text { Proportion of bathers } \\
\text { reporting the following }\end{array}$ & \multicolumn{2}{l}{ Sensation of draughts } & \\
\cline { 2 - 3 } symptoms at least once $(\%)$ & No & Yes & p value \\
\hline Itch & $19 \cdot 3$ & $44 \cdot 1$ & $\mathrm{p}=0.0023$ \\
Rash & $6 \cdot 3$ & 17.6 & $\mathrm{p}=0.0449$ \\
Runny nose & 32.9 & 61.8 & $\mathrm{p}=0.002$ \\
Cough & 7.0 & 23.5 & $\mathrm{p}=0.009$ \\
\hline
\end{tabular}

Bathing behaviour was quite similar at primary and at middle school, and was probably enforced by swimming instructors. Showering before and after bathing and wearing swimming goggles and caps were, however, individual habits. It is unfortunate that washing was so infrequent because, according to Perron ${ }^{15}$ a shower subsequent to bathing using soap at a pH close to skin $\mathrm{pH}$ is necessary to avoid skin xerosis. Use of swimming goggles and caps was particularly common in the primary pupils, perhaps because they are more affected by the water than older children and probably because their mothers insist.

Self reporting of symptoms is, of course, a subjective action. Moreover, subjects are aware of their exposure and bathers who are dissatisfied with the comfort of the swimming pool environment are inclined to over-report their symptoms. There are statistically significant relationships between the sensation of draughts and reporting of four signs. Such results are difficult to explain and it may be wondered whether the sensation of draughts is a cause or a consequence of the reported signs. In spite of these four associations, over reporting of symptoms seems to be a minor source of bias in this study.

Comparison of symptoms in bathers and nonbathers supports the not surprising conclusion that swimming generally increases the risk of minor ailments, particularly of eye disorders. Findings concerning eye irritation support a causal relationship between exposure and red or watery eyes. These troubles were observed on each week and in each pool; their latency and their duration were short since they occurred on the bathing day and resolved spontaneously over one day.

This outcome agrees with results from several authors. According to Peyronnet et al, ${ }^{16} 42 \cdot 3 \%$ of bathers complain of eye disorders. Haag and Gieser $^{17}$ found that $68 \%$ of public pool users experienced halo effects after an average of 34 minutes' swimming; $94 \%$ of subjects also exhibited corneal erosions. Soni et al $^{18}$ noted greater than average corneal thickness in a group of competitive swimmers.

Is eye irritation caused by chlorine or its mineral or organic byproducts? ${ }^{19}$ Rylander et al ${ }^{20}$ think that monochloramine is more irritating than free chlorine or organic chloramine. According to Laurent et $a l^{21}$ the trihalomethanes may contribute to mucocutaneous irritation and their role must be explored. Chiswell and Wildsoet ${ }^{19}$ suggest that the corneal reactions in competitive swimmers are $\mathrm{pH}$ related and recommend that the $\mathrm{pH}$ of pool water be slightly alkaline because lower $\mathrm{pH}$ values favour the formation of $\mathrm{HOCl}$, the more powerful oxidising but also disinfecting agent. At least some of the symptoms experienced by swimmers can be attributed to the hypotonic nature of swimming pool water. The normal environment of the external eye is the tear film which has a salt concentration between 0.90 and $0.95 \%$ of $\mathrm{NaCl}$ while the salt concentration in standard chlorinated swimming pool water is negligible $(<0.05 \%)$. The corneal epithelium is extremely sensitive to hypotonic solutions.

This study does not allow us to support any one particular hypothesis. Chloramines, indirectly estimated through combined chlorine elvels, were in slight excess on three occasions during the survey but the frequency of eye irritation was not consequently changed. The salt concentration was determined and came to about $10 \mathrm{MEq} \mathrm{NaCl} / 1$ that is below the values corresponding to the occurrence of corneal reactions. $\mathrm{pH}$ is slightly alkaline.

Is there any advice that can be given to bathers to help avoid eye irritation? No single piece of advice for action sems to be mandatory. Nevertheless, it seems advisable to wear swimming goggles. It is not necessary to reduce the duration of exposure to water since eye irritation does not depend on bathing duration. The contribution of head-immersion as a risk factor is unclear. According to our findings, swimming with the head under water and the eyes open would protect against watery eyes! But this illustrates bias-the "healthy worker effect".

The incidence of otolaryngological disorders (runny nose, sore throat) was higher, but the difference not statistically significant, in bathers compared with non-bathers. This result could be explained by a lack of statistical power, the number of children being small. But the most likely reason is that these disorders are not due to contamination in situ; sometimes they may occur after bathing, in subject pathogen carriers, after fatigue and changes in temperature or draughts.

This survey does not allow us to draw clear conclusions from results relating to earache and verrucas. Indeed, only 36 pupils never bathed during the survey and were referred to as nonbathers: $58 \%$ of them were exempt from swimming because of ill health, $22 \%$ because of verrucas, and $17 \%$ because of recurrent otitis. With these "controls" it is probable that the frequency of these symptoms is overestimated in nonexposed subjects. For instance, $8.3 \%$ of nonbathers suffer from earache in our study $v 3 \%$ in other reports. ${ }^{22}$ On the other hand, the prevalence of this sign in bathers seems to be consistent with that published elsewhere. ${ }^{23}$ This issue would involve an underestimation of risk associated with swimming in a pool. However, Seyfried et $a l^{24}$ showed a relationship between ear infections and the presence of Pseudomonas aeruginosa in the pool water. Our bateriological analyses did not find this bacterium. 
As for verrucas, their frequency in this investigation is overestimated in children who did not swim and underestimated in those who did since pupils exempted from swimming because of verrucas might have caught these verrucas after a previous exposure in a pool. Only the prevalence of verrucas in the college can therefore be estimated.

These last two problems deserve further consideration. Overall, bathing in a well-kept school swimming pool does not produce any major health hazard except eye irritation.

The authors wish to thank the director of the College, the director of the pool complex, the school physician and his colleagues, the teachers, the vice-principals, and the parents of pupils attending this College for their participation. They are also grateful to Dr Houette and to Mrs Morlaye and Mrs Saunoi for their able technical assistance.

1 Kappus KD, Marks JS, Holman RC, et al. An outbreak of Norwalk gastroenteritis associated with swimming in a pool and secondary person-to-person transmission. $\mathrm{Am} f$ Epidemiol 1982; 116: 834-9.

2 Porter JD, Ragazzoni HP, Buchanon JD, Waskin HA, Juranek DD, Parkin WE. Giardia transmission in a swimming pool. Am 7 Public Health 1988; 78: 659-62.

3 Holmes SE, Pearson JL, Kinde MR, Hennes RF. Gastroenteritis outbreak: diseases linked to swimming pool and spa use. 7 Environ Health 1989; 51: 286-8.

4 Lenaway DD, Brockmann R, Dolan GJ, Cruz-Uribe F. An outbreak of an enterovirus-like illness at a Community wading pool: implications for Public Health Inspection wading pool: implications for Public Health Insp

5 Caldwell GG, Lindsey NJ, Wulff H, Donnelly DD, Bohl FN Caldwell GG, Lindsey NJ, Wulff $\mathrm{H}$, Donnelly DD, Bohl FN.

6 D'Angelo LJ, Hierholzer JC, Keenlyside RA, Anderson LJ, Martone WJ. Pharyngoconjunctival fever caused by adenovirus type 4: report of a swimming pool related outbreak with recovery of virus from pool water. $\mathcal{F}$ Infect Dis 1979; 140: 42-7.

7 Martone WJ, Hierholzer JC, Keenlyside RA, Fraser DW, D'Angelo LJ, Winkler WG. An outbreak of adenovirus type 3 disease at a private recreation center swimming pool. $A m \mathcal{F}$ Epidemiol 1980; 111: 229-37.

8 Turner $M$, Istre $G$, Beauchamp $\mathrm{H}$, Baum $\mathrm{M}$, Arnold $\mathrm{S}$. Community outbreak of adenovirus type $7 \mathrm{a}$. Infections associated with a swimming pool: Southern Medical foumal 1987; 80: 712-5.

9 Mahoney FJ, Farley TA, Kelso KY, Wislon SA, Horan J, MacFarland LM. An outbreak of hepatitis A associated with MacFarland LM. An outbreak of hepatitis A associated with

10 Switalny KC, Vogt RL, Witherell LE. National survey on Spitalny KC, Vogt RL, Witherell LE. National survey on
outbreaks associated with whirlpool spas. Am f Public Health outbreaks associated

11 Ratnam S, Hogan K, March SB, Butler RW. Whirlpoolassociated folliculitis caused by Pseudomonas acruginosa: report of an outbreak and review. F Clin Microbiol 1986; 23 : $655-9$.
12 Bornstein N, Marmet D, Surgot M, et al. Exposure to legionellaceae at a hot spring spa: a prospective clinical and serological study. Epidem Inf 1989; 102: 31-6.

13 (i) Loi ${ }^{\circ} 78-733$ du 12 Juillet 1978. Relative aux piscines et aux baignades aménagées. Paris: Fournal Officiel du 13 Juillet 1978

(ii) Décret $n^{\circ} 81-324$ de 7 Avril 1981. Fixant les normes d'hygiène et de sécurité applicables aux piscines et aux baignades aménagées. Paris: Fournal Officiel du 10 Avril 1981

(iii) Arrèté du 7 Avril 1981. Fixant les dispositions techniques applicables aux piscines. Paris: Fournal Officiel du 10 Avril 1981.

(iv) Arrêté du 7 Avril 1981. Fixant les dispositions administratives applicables aux piscines et aux baignades aménagées. Paris: foumal Officiel du 10 Avril 1981.

(v) Circulaire du 9 Mai 1983. Relative aux piscines et à la mise en conformité des installations existantes. Foumal Officiel du 13 Août 1983 .

(vi) Arrêté du 28 Septembre 1989. Modifiant l'arrêté du 7 Avril 1981, fixant les dispositions techniques applicables aux piscines. Paris: Gournal Officiel du 21 Octobre 1989.

(vii) Décret $n^{\circ} 91-980$ du 20 Septembre 1991. Modifiant le décret $\mathrm{n}^{\circ} 81-324$ du 7 Avril 1981 fixant les normes d'hygiène et de sécurité applicables aux piscines et aux baignades aménagées. Paris: foumal Officiel du 26 Septembre 1991.

(viii) Arrèté du 29 Novembre 1991. Pris pour l'application du décret n $91-980$ du 20 Septembre 1991 modifiant le décret $n^{\circ} 81-324$ du 7 Avril 1981 fixant les règles d'hygiene et de sécurité applicables aux piscines et aux baignades aménagées. Paris: Fourmal Officiel du 7 Janvier 1992.

14 Hogue CJ, Gaylor DW, Schul\% KF. Estimators of relative risk for case-control studies. Am f Epidemiol 1983; 118: 396-407.

15 Perron J. Pathologies des piscines. Gazette Medicale 1988 95. $34-40$.

16 Peyronnet P, Spinasse A, Dab W, Le Moullec Y, Festy B. Perception par l'usager des facteurs d'environnement à l'intérieur des établissements de natation ouverts au public à Paris. Foumal Français d'Hydrologie 1988; 19: 217-30.

17 Haag JR, Gieser RG. Effects of swimming pool water on the cornea. FAMA 1983; 249: 2507-8.

18 Soni PS, Pence NA, De Leon L, Lawrence S. Feasibility of extended wear lens use in chlorinated swimming pools. American fournal of Optometry Physiology and Optics 1986; 63: 171-6.

19 Chiswell B, Wildsoet CF. The causes of eye irritiation in swimming pools. Water Science and Technology 1989; 21 241-4.

20 Rylander R, Victorin K, Sorensen S. The effect of saline on eye irritation caused by swimming pool water. foumal of Hygiene 1973; 71: 587-92.

21 Iaurent AM, Le Moullec Y, Festy B. Formation de composés haloformes dans les eaux de piscines traitées par le chlore ou le brome. Foumal Français d'Hydrologic 1983; 40: $89-103$.

22 Spinasse A, Squinazi F, Festy B. Risques infectieux et piscines. Infectiologie 1989; 28: 8-14.

23 Calderon RL, Mood EW. Epidemiological studies of otitis externa: report of a prospective and of a retrospective study of otitis externa among swimmers. Finvironmental Protection Agency 1981; 600/S1 81.053.

24 Seyfried PL, Tobin RS, Brown NE, Ness PF. A prospective study of swimming-related illness. I Swimming-associated health risk. Am F Public Health 1985; 75: 1068-70. 